\title{
LIETUVOS REPUTACINIO ELITO TYRIMO ŠALTINIAI
}

\author{
Valdas Selenis \\ Lietuvos kultūros tyrimų instituto \\ Baltų ir Lietuvos kultūros istorijos skyrius \\ Saltoniškių g. 58, Vilnius, Lietuva \\ Tel. 852751898 \\ El. paštas: valdas.selenis@lkti.lt
}

Pateiktas 2014 m. kovo 18 d., parengta spausdinti 2015 m. sausio 3 d.

doi:10.13165/SMS-14-6-3-04

Anotacija. Europoje XIX-XX a. pradžioje formuojantis modernioms tautoms ir nacionalinèms valstybèms pradèta leisti nacionalinius reputacinius elitus - pasižyméjusius politikos, kultūros, mokslo ir kitu sričiu žmones fiksuojančius leidinius. Enciklopedijos ir biografiniai žinynai tapo savotiškomis "garbès lentomis“. Nacionalinio reputacinio elito formavimosi mechanizmo 1918-1940 metu Lietuvos Respublikoje tyrimu dar néra. Klausimai, kokie sociokultūriniai, socioistoriniai ar politiniai veiksniai darè ìtaka iškiliausiu visuomenès ir valstybès veikejju reprezentacijai, laukia tolesniu tyrimu. Šiame straipsnyje aptariami Lietuvos XX a. reputacinio elito šaltiniai ir ju reikšmé įamžinant žymiausius visuomenés veikejjus, taip pat ju atrankos kriterijai taikant dokumentu analizés metoda. Statistiniai metodai tyrimui nèra pasitelkti, nes kiekybiniam tyrimui reiktu pasirinkti laikotarpi, šaltinius arba šaltini, išskirti tikslinę tiriama grupę, o tai yra atskiro darbo dalykas. Daugiausia demesio skiriama XX a. pirmajai pusei, kai Lietuvoje atsirado pirmieji tokio pobūdžio šaltiniai. Straipsnio išvados rodo, kad statistinius tyrimus atlikti būtu sudètinga, o jų rezultatai nebūtų reprezentatyvūs dèl šaltinių pobūdžio. Pirmosios Lietuvos Respublikos (1918-1940) laiku šaltiniai - „Lietuviškoji enciklopedija“ buvo išleista ne visa, „Lietuvos žymesnybiu žodynas“ išvis nebuvo publikuotas, be to, neišliko

Socialinių mokslų studijos / Societal Studies

(C) Mykolo Romerio universitetas, 2014

(C) Mykolas Romeris University, 2014
ISSN 2029-2244 (online)

http://www.mruni.eu/lt/mokslo_darbai/SMS/ http://www.mruni.eu/en/mokslo_darbai/SMS/ 
vieno tomo mašinraštis. Sovietmečio enciklopedijų atranka buvo daroma pagal „partinį“" arba "technokratini" principa. Antrosios Lietuvos Respublikos (nuo 1990) reputacinio elito tyrimo šaltiniai arba komercializuoti, arba dar ne visi išleisti.

Reikšminiai žodžiai: reputacinis elitas, enciklopedijos, biografiniai žinynai.

\section{Ivadas}

Šiame straipsnyje reputaciniu elitu laikomi žymiausi, autoritetingiausi, „labiausiai nusipelnę valstybei ir tautai“, ịtakingiausi visuomenès "garsūs žmonès“ (angl. men of fame), apdovanotieji premijomis, ordinais ir kitokiais ivertinimo atributais, taip pat visi asmenys, patekę i enciklopedijas ir „kas yra kas“ (angl. who is who) pobūdžio leidinius. Kultūrologas Leo Braudy teigia, kad žymaus asmens reputaciją (angl. fame) visuomeneje sudaro keturi elementai: pats žmogus, jo pasiekimai, jų viešumas ir ką ainiai galvoja apie juos dabar ${ }^{1}$. Kaip tą reputaciją objektyvizuoti ir padaryti empirinio tyrimo objektu? Žymus prancūzų sociologas Pierre'as Bourdieu skyre intelektualų ,išorinę“ ir „vidinę" reputaciją. Jo nuomone, „intelektualų laukas“ yra autonomiškesnis, jeigu vadovaujasi savomis vertybėmis, normomis, taisyklemis, nepriklausomai nuo „išorinès" reputacijos ir žinomumo. Tačiau mokslininkai gali tirti, kaip atitinkamos profesijos žmonių „vidinë“ reputacija buvo vertinama visuomenès „išorèje“2.

Vakarų Europoje biografinio pobūdžio informacijos apie „ižymybes“ skelbimo tradicija siekia Apšvietos epochos enciklopedijas - modernių enciklopedijų pirmtakes, o XIX a. pabaigoje - XX a. pradžioje biografiniai žinynai tapo imperinių ir modernaus nacionalizmo epochoje besiformuojančių „mažųjų“ tautų žymiausių tautinių ir valstybinių veikèjų „kanonizavimo“ forma.

Biografinių žodynų tikslas „ireminti“ tautą. Specifinès institucijos ar bent jau dideli jų padaliniai buvo ịkurti, siekiant išleisti nacionalines enciklopedijas, kurių rengimas užtrukdavo daug metų, kartais ir dešimtmečių. 1845 metais Académie Royale des Sciences, des lettres et des beaux-arts Briuselyje sutelkè komisiją Biographie Nationale leidimui. Šis projektas tapo ịstabiu 1830 metais atsiradusios Belgijos karalystès paminklu. Belgais šioje enciklopedijoje buvo ịvardinti žmonès, gimę Belgijoje arba tose teritorijose, kurios kurị laiką priklausè Belgijai. Enciklopedija pradèta rengti 1851 metais, bet darbai vyko lètai, 28 tomai išleisti 1866-1944 metais. Netrukus nacionalinès arba valstybinès enciklopedijos ir biografiniai žodynai pradèti leisti Olandijoje, Danijoje, Italijoje, Anglijoje, Austrijos ir Rusijos imperijose. Enciklopediju statusas ir vertè skyrèsi, asmenybių atranką darè akademinès institucijos, o Anglijos atveju - leidejai ${ }^{3}$.

1 Braudy, L. The Frenzy of Renown. Fame and its History. New York, Ofxord, 1986, p. 15.

2 Bourdieu, P. L'illusion biographique. Actes de la recherche en sciences sociales. 1986, 62/3: 69-73.

3 Varga, M. Dictionaries of National Biography. Atlas of European Historiography. The Making of a Profession 1800-2005, ed. I. Porciani, L. Raphael, Palgrave Macmillan, 2010, p. 27. 
Reputacinio elito socioistorinių tyrimų nèra daug ne tik Lietuvos, bet ir pasaulinejje sociologinèje, tuo labiau istoriografinèje literatūroje. Kaip šiuo metu aktyviausią tokių tyrimų iniciatorių galima paminèti Vengrijos reputacinio elito tyrimus atliekantị, taip pat tarptautinėms programoms vadovaujantị sociologą, buvusị Pierre'o Bourdieu bendradarbị, dabar Centrinès Europos universiteto profesorių emeritą Victorą Karady ${ }^{4}$. Irmina Matonytė pateikè elito tipologiją: meritokratinis, nuopelnų elitas - tai žmonès, turintys ypatingų savybių, bet nebūtinai valdžią ${ }^{5}$. Funkcinio (arba reputacinio) elito samprata kreipia pirma nustatyti, kas yra ittakingas, ir tada tuos asmenis pripažinti galių elitu. Tačiau tokia tyrimo koncepcija iškelia kitokią problemą - subjektyvumo demenį, nes tik nuo „ekspertinių“ vertinimų ar kitokių gana subjektyvių samprotavimų priklauso, kas yra laikomi funkcinio elito atstovais, o kas ne.

2012 m. vasario 3-4 d. Budapešto Vidurio Europos universitete vyko seminaras „Reputational Elites in Small European Nation States (19-20 th Centuries)“ reputacinių elitų mažosiose nacionalinėse Europos valstybėse XIX-XX amžiais klausimais. Buvo aptariamos tarptautinio tyrimų projekto galimybès ${ }^{6}$. Ji moderavo Viktoras Karady. Tačiau šis projektas dèl lèšų trūkumo nebuvo pradètas.

Georgeta Nazarska parengè pranešimą Europos socialinès istorijos konferencijai, vykusiai 2014 m. balandžio 23-26 d. Vienoje, (Austrija), apie moteris Bulgarijos reputaciniame elite XIX a. pabaigoje ir iki $1950 \mathrm{~m}$. Ji teigia, kad Bulgarijoje, kaip ir kitose nacionalinėse valstybėse, „nacionalinị projektą“, t. y. - tautą, kūrè elitai, sukurdami simbolinę sistemą, per kurią legitimizavosi jie patys: įtraukiant ị biografinius žodynus ir enciklopedijas, sukuriant literatūrinị kanoną, jų vardu pavadinant gatves ir institucijas, ịkuriant valstybinius apdovanojimus ir dekoracijų sistemą ${ }^{7}$.

Straipsnio tikslas - aptarti Lietuvos valstybės reputacinio elito tyrimo šaltinius. Uždaviniai - išskirti svarbiausius XX a. pasirodžiusius enciklopedinius leidinius ir tuo metu jų leidejų ir redaktorių taikytus „žymių žmonių“ atrankos kriterijus.

\section{Reputacinio elito tyrimo šaltinių alternatyvos}

Gali būti keli reputacinio elito išskyrimo būdai, pavyzdžiui, reputacinis elitas gali būti atrenkamas ir tokiu būdu, kurị pasirinko projekto „Iškiliausi tarpukario kauniečiai“ organizatoriai - atrankai atlikti buvo sudaryta komisija iš istorikų, bibliotekininkų, architektų, žurnalistų ir kt., be to, 35 asmenų sąrašą sudarẻ Kauno apskrities

4 Karady, V. Educated Elites in Pre-Socialist Hungary - 1867-1948. Issues, Approaches, Sources and Some Preliminary Results of an Overall Survey. Historical Social Research. 2008, Vol. 33, Issue 2: 154-173.

5 Masiulis, K.; Sudnickas, T. Elitas ir lyderystè. Vadovèlis. Vilnius: Mykolo Romerio universiteto leidybos centras, 2008, p. 20; Matonytè, I. Posovietinio elito labirintai. Vilnius: Knygiai, 2001.

6 Seminaras [interaktyvus]. [žiūrèta 2014-02-04]. <https://history.ceu.hu/events/2012-02-03/ reputational-elites-in-small-european-nation-states-19-20th-centuries $>$.

7 Nazarska, G. Women in Bulgarian Pre-Socialist Reputational Elites [interaktyvus]. [žiūrèta 2014-02-04]. <https://esshc.socialhistory.org/esshc-user/program/?day=12\&time=21\&paper=1780 $>$. 
Viešosios bibliotekos Kaunistikos skaityklos darbuotojai ir Vytauto Didžiojo universiteto (toliau VDU) Istorijos fakulteto akademinè bendruomenè. Pagrindiniai atrankos kriterijai: nuopelnai Kauno miestui ir šių darbų išliekamoji verte šiandien, žmonès novatoriai ${ }^{8}$. Šiuo atveju taikytas vadinamasis reputacinis metodas: respondentai apklausiami, kuo žymus vienas ar kitas žmogus, ar prašomi nurodyti tokius ${ }^{9}$. Tačiau amžininkų nuomonè apie to meto elitą išreikšta tik tuo pat laikotarpiu išleistose ir parengtose nacionalinèse enciklopedijose, todèl jos gali būti pagrindinis tyrimo šaltinis.

Reputacinio elito vardais pavadinamos gatvès, skverai, parkai, rajonai ir kt. objektai, steigiamos jų vardo premijos ir kiti vardiniai apdovanojimai ir, žinoma, jiems statomi paminklai. Rasos Čepaitienès nuomone, gana artimas amerikietiškam modeliui - „valstybès tèvų“ - kultas buvo ir pirmajame pirmosios Lietuvos Respublikos dešimtmetyje: „Tautos patriarchas“ Jonas Basanavičius pradètas įamžinti jam dar gyvam esant, kai 1923 metais laikinosios sostinès Karo muziejaus sodelyje ịvyko pirmo Jono Basanavičiaus paminklo atidengimas. Beje, J. Basanavičius iki tol jau buvo gausiai ịamžintas, ką rodytų, pavyzdžiui, jo užimama pirmoji vieta istorinèms asmenybèms skirtuose Lietuvos miestų gatvių pavadinimuose ${ }^{10}$.

Valstybei nusipelnę žmonès buvo apdovanojami ypatingais ženklais - ordinais ir medaliais. Čia turèjo būti vykdoma atranka. Antai Pirmosios Lietuvos Respublikos gyvavimo pabaigoje buvo nustatyta nauja tvarka „pristatyti kandidatams apdovanoti Vytauto Didžiojo ir D.L.K. Gedimino ordinams tų ordinų švenčių proga - rugsèjo 8 d. ir vasario 16 d.: 1 . Vytauto Didžiojo ordinu apdovanoti pristatomi asmens tik išimtinais, retais atsitikimais, už ypatingus nuopelnus Lietuvos valstybei, lietuvių tautos garbei ir žmonijos gerovei“. Švietimo ministerijai nustatomas kandidatų maksimumas - ne daugiau kaip 15 asmenų, DLK Gedimino ordinu taip pat apdovanojama ne daugiau kaip $15^{11}$. Be to, Vytauto Didžiojo ordino taryba pareiške pageidavimą priminti ministerijoms ir ịstaigoms, kad pristatymuose apdovanoti Vytauto Didžiojo ordinais būtų tiksliau apibūdinami ypatingieji pristatomųjų nuopelnai ir griežčiau laikomasi „Ordinų, medalių ir kitų pasižymèjimų garbės ženklų ịstatymo str. $88^{\text {“12. }}$.

Enciklopediniai leidiniai paprastai apima ir žymiausius žmones, kuriems statomi paminklai, jų vardais pavadinamos gatvès, apdovanuotuosius ordinais ir premijomis, todèl enciklopedijas ir biografinius žinynus galima laikyti patogiausiais ir išsamiausiais reputacinio elito tyrimo šatliniais.

8 Urbonavičienè, E. Projektas „Iškiliausi tarpukario kauniečiai“. Kauno istorijos metraštis. T. 12. Kaunas: VDU leidykla, 2012, p. 257-259.

9 Research Methods for Elite Studies, edited by George Moyses and Margaret Wagstaffe. Department of Government, University of Manchester, London, Allen , Boston-SydneyWellington, p. 31.

10 Čepaitienè, R. Nacionalinis miestas (III) [interaktyvus]. [žiūrèta 2014-02-10]. <http://www. bernardinai.lt/straipsnis/2013-01-23-rasa-cepaitiene-nacionalinis-miestas/94144/print>.

11 Respublikos Prezidento aktai (apdovanojimai). LCVA. f. 391, ap. 6, b. 47, 1. 1.

12 Lietuvos Respublikos Prezidento kanceliarijos 1939 m. spalio 9 d. laiškas Švietimo ministrui. LCVA. f. 391, ap. 6, b. 47, 1. 9. 


\section{Reputacinio elito tyrimo šaltinių XX a. pradžioje atsiradimo prielaidos}

Knygotyrininkai teigia, kad pirmieji 1910 metais iškèlę idejją leisti nacionalinę enciklopediją Lietuvoje ir JAV vienu metu buvo Mykolas Biržiška - pasiūlè igyvendinti projektą Lietuvių mokslo draugijos pajègomis, o JAV analogišką pasiūlymą pateike Juozas Gabrys, po to greitai ji pasigavo Antanas Olšauskas ${ }^{13}$. Tačiau archyviniai šaltiniai rodo, kad nacionalinès enciklopedijos idejos autorius buvo Mečislovas Davainis-Silvestraitis. Jau 1907 metais jis raše kitam lietuvių inteligentui Jurgiui Šauliui taip: „Tegul jau ką gero dèl tautos padaryti, tai jauni mūsų inteligentai gerai padarytų suvartoję savo energiją dẻl išleidimo „Lietuviškos enciklopedijos“ ant pavidalo latviškos „Konversacijos Wardnica“. Turi jau mokslo draugija su jos pagalba galetų ši tą padaryti, prenumeratorių ant tokios enciklopedijos atsirastų i kelius tūkstančius, kas duotų išgalèjimą ją leisti. Kad ji būtų ịvairesnè nuo kitų enciklopedijų, tai reikia ten daugiau talpinti iš lietuviškos istorijos, geografijos, etnografijos, gamtos ir t. t. ${ }^{14}$ Lygiai po septynerių metų jis paraše prašymą Vilniaus gubernatoriui dèl lietuviškos enciklopedijos pavadinimo „Lietuviškoji enciklopedija“, taip pat ir enciklopedijos lenku kalba „Encyklopedia Litewska“, kurias ketino leisti ir redaguoti ${ }^{15}$. Reiktų pažymèti, kad išliko M. Davainio-Silvestraičio „Lietuviškajai enciklopedijai“ rinkta medžiaga, tačiau joje asmenybių biogramų nèra ${ }^{16}$.

Pirmojo tomo „Zžangos žodyje“ V. Biržiška rašè, kad 1910 metais „Vienybès lietuvninkų“ redakcijoje M. Biržiškos redaguotoje „Visuomeneje“ ir Juozo ParšaičioGabrio „Tèvynejje“ keltas „Lietuviškojo žinyno“ sumanymas. Mintị peremė „Lietuvos“leidejjas Antanas Olševskis (Olšauskas) ir pakvietė Klemensą Jurgelionį sudaryti enciklopedijos redakciją, o šis kreipèsi į Lietuvos intelektualus. Pavyzdžiu jai rengti pasirinktos angliškoji „Encyclopedia Britannica“ ir vokiečiu „Brockhaus“. Tačiau 1912 metais leidejjas sumanymo atsisakè, nes „ivairių srovių“ bendradarbiai negaléjo susitarti dèl straipsnių pobūdžio, be to, enciklopedijos leidyba pareikalautų žymiai daugiau lèšų, negu buvo numatyta. 1912 metais, deja, ịvykus ịvairiems nesusipratimams „vietiniai“ lietuvių redaktoriai pasitraukè, o JAV daugiau lietuvių inteligentų, norinčių užbaigti enciklopedijos rengimo darbus, nebuvo įmanoma rasti.

13 Glosienè, A. „Lietuviškoji enciklopedija“ ir „Žymesnybių žodynas“: leidimo problemos. Knygotyra. 1993 (1994), 20: 61.

14 Mečislovo Davainio-Silvestraičio laiškas Jurgiui Šauliui, 1907-07-09, LLTI, f. 115, b. 145, 1. 1.

15 Davainis-Silvestraitis, M. Prašymas Vilniaus gubernatoriui. 1914-07-07, LLTI, f. 1, b. 1761, 1. 1. Už nuorodą dèkoju Lietuvos istorijos instituto istorikei Olgai Mastianicai. 


\section{Reputacinio elito tyrimo šaltiniai Lietuvos Respublikoje 1918-1940 metais}

Neskaitant 1920-1922 metais Lietuvos Respublikos Steigiamajam Seimui skirto leidinio, kuriame trumpai pristatyti tautos išrinkti atstovai ị pirmąji atkurtos valstybès parlamentą ${ }^{17}$, pagrindiniai atkurtosios Lietuvos valstybès reputacinị elitą fiksuojantys leidiniai buvo šie:

1. Lietuvos albumas. Kaunas, 1921. Pirmasis Lietuvos valstybei ir visuomenei nusipelniusių žmonių biografijų leidinys. Praẻjus dešimtmečiui H. Serapino parengtas spaudai Vytauto Didžiojo mirties 500 metu sukaktuvems paminèti albumas ir 1933 metais išleistas Kaune yra kitokio pobūdžio - iš esmès ikonografinis šaltinis be biografiniu straipsnių. Jame užfiksuoti 1930 metais ịvairiose valstybinèse institucijose ar sėkmingai veikusiose įmonèse dirbę žmonès (daugiausia -vadovai), bet speciali jų atranka ị leidinį nebuvo vykdoma.

2. Lietuvos žymesnybiu žodynas. T. 1-5. LKMA tikrinimo komisija Z. Ivinskis, J. Girnius, A. Salys (vidutine apimtis 544-612 p.). Kaunas, 1931. Pirmasis Kas yra kas pobūdžio biografinis žinynas, inicijuotas Lietuvių katalikų mokslo akademijos ir likęs nepublikuotas. Mašinraštis saugomas Lietuvos nacionalinėje Martyno Mažvydo bibliotekoje (F. 130-1460, 1461, 1462, 1463) (3 tomo nèra).

3. Lietuviškoji enciklopedija. Leidèjas „Spaudos fondas“. T. 1-10 (A-Ilirizmas) (vidutinè apimtis 700-800 p.), red. Vaclovas Biržiška. Kaunas, 1931-1941 (1944). Vienintelè 1918-1940 m. Lietuvos Respublikos enciklopedija su plačiais ir informatyviais biografiniais straipsniais, tačiau dèl sovietinès ir nacių okupacijos išleista tik 10 tomų (baigiasi raide J). Peržvelgta dešimt „Lietuviškosios enciklopedijos“ tomų ${ }^{18}$, ši enciklopedija buvo leidžiama 12000 egzempliorių tiražu.

Pažymètina, kad išsamiausias reputacinio elito tyrimo enciklopedinis šaltinis galètų būti ir Bostone leistoji „Lietuvių enciklopedija“, tačiau šis leidinys buvo rengiamas jau nebeegzistuojant valstybei. Vèlesnio laikotarpio enciklopedijose įtraukiama asmenų, kurie dar nebuvo pripažinti savo amžininkų, o jų darbų reikšmé ịvertinta praejjus dešimtmečiams.

1921 metais „Lietuvos albume“ leidèjas (Liudas Gira) pažymėjo, kad „mūsų svarbiai ir ịdomiai gadynei tinkamai apibūdinti reikia ne tik faktų istoriją duoti, bet ir

17 Trumpos Steigiamojo Seimo nariu biografijos su atvaizdais. Klaipeda: Seimo kanceliarija, 1921, $74 \mathrm{p}$.

18 T. 1, A-Atskalūnas, leidejjas „Spaudos Fondas“. Kaunas, 1933, 1534 p.; t. 2, Atskilèlis-Batoras, leidejjas „Spaudos Fondas“. Kaunas, 1934, 1534 p.; t. 3, Batoras-Bohatta, leidejas „Spaudos Fondas“. Kaunas, 1935, 1534 p.; t. 4, Bogdanas-Caxias, leidejas „Spaudos Fondas“. Kaunas, 1936, 1534 p.; t. 5, Caxias-Darbininkų Viltis, leidejas „Spaudos Fondas“. Kaunas, 1937, 1534 p.; t. 6, Darbininkų Žodis-Drugenis, leidejas „Spaudos Fondas“. Kaunas, 1937, 1534 p.; t. 7, DrugiaiFazmos, leidejas „Spaudos Fondas“. Kaunas, 1939, 1534 p.; t. 8, F.B.A.-Ginhac, leidejjas „Spaudos Fondas“. Kaunas, 1940, 1534 p.; t. 9, Gini-Höfer, leidejjas „Valstybinè leidykla“. Kaunas, 1941, 1534 p.; t. 10, Höfer-Ilirizmas, leidejas „Valstybinè leidykla“. Kaunas, 1944, 897 p. 
parodyti tie žmones, kurie daugiau ar mažiau savo iniciatyva bei darbu prisidejo prie lietuvių tautos ir valstybės atgaivinimo" ${ }^{19}$. Renkant atvaizdus ir biografijas daugiausia pasidarbavo Janina Markevičiūtè ir Liudas Gira, kuris atliko galutinị „Lietuvos albumo“ sutvarkymo ir redagavimo darbą. Leidinys nebuvo išsamus, bet pirmasis „tos rūšies leidinys“. Reikia pažymèti, kad šis, ankstyviausias iš visų 1918-1940 metais Lietuvos Respublikos biografinių leidinių, pateikè tokių itin ryškių reputacinio elito atstovų biografijas, kurių dèl suprantamų priežasčių nerasime „Lietuviškojoje enciklopedijoje“ (toliau -LE) ir rankraštiniame "Žymesnybių žodyne“ (toliau - ŽŽ). Pirmuoju atveju - dešimtasis enciklopedijos tomas užsibaigè raide „“, antruoju dingęs visas trečiasis žodyno tomas. Pavyzdžiui, Lietuvos nacionalinèje bibliotekoje saugomame Vaclovo Biržiškos fonde (f. 32) nèra Antano Smetonos biografijos net rankraštiniu pavidalu, nors darbiniame asmenvardžių sąraše yra lapelis su duomenimis apie $\mathrm{jit}^{20}$. Tačiau išsami biograma apie Vytauto Didžiojo universiteto Humanitarinių mokslų fakulteto Meno teorijos ir istorijos katedros docentą, publicistą, visuomenininką, LR prezidentą, „Tautos Vadą“ yra ŽŽ ${ }^{21}$. „Lietuviškąją enciklopediją“ leido „Spaudos fondas“ bendradarbiaudamas su Lietuvių katalikų mokslų akademija. Vyriausiąą Lietuviškosios enciklopedijos redakciją sudarė vyriausiasis redaktorius profesorius Vaclovas Biržiška, viceredaktorius profesorius Pranas Dovydaitis, redakcijos nariai profesorius Mykolas Biržiška, profesorius Blažiejus Čèsnys, profesorius Vincas Krèvè-Mickevičius, profesorius Vladas Lašas ir Vincas Kvieska, redakcijos sekretoriai buvo Pranas Čepènas ir Bronius Vaitiekūnas.

1923-1924 metais „Švyturio“ bendrovei Vilniuje ir Kaune išplètus knygų leidybos mastus, enciklopedijos ideja atgijo, tačiau dèl materialinių sunkumų nebuvo igyvendinta. 1924 metų gruodị V. Biržiškai pasiūlius, Šiaulių „Kultūra“ buvo nutarusi leisti ne bendrąją, bet grynai lietuviškų dalykų enciklopediją ir pavedè sumanytojui sudaryti redakciją. Tačiau materialiniai sunkumai vèl sustabde jau pradètą darbą. Pagaliau 1929 metais Lietuvos kultūros taryba vèl iškèlè šią idejją ir atkreipé „Spaudos fondo " dèmesị, jis $1929 \mathrm{~m}$. gruodžio $21 \mathrm{~d}$. nutare enciklopediją leisti ir $1930 \mathrm{~m}$. sausio 25 d. prièmé jos leidybos planą. V. Biržiška buvo pakviestas būti vyriausiuoju redaktoriumi ir darbo organizatoriumi. Beveik tuo pat metu panašus sumanymas kilo ir Lietuvos katalikų mokslų akademijoje (toliau - LKMA), todèl galèjo susidaryti tokia padètis, kad vienu metu būtų pradètos leisti dvi enciklopedijos. Prasidejo derybos ir 1930 m. gegužès 22 d. susitarta bendradarbiauti. Sutartis pasirašyta tik $1931 \mathrm{~m}$. kovo 5 d. Tuomet suformuota redakcija, sukurtas ir atskiras „karo“ skyrius. Pirmasis enciklopedijos sąsiuvinis pasirodè $1931 \mathrm{~m}$. spalio $1 \mathrm{~d}$. Enciklopedija iš pradžių turèjo 6000 prenumeratorių - kaip pažymi V. Biržiška, tai „žmonès, gauną neaukštą atlyginimą ar uždarbị“.

19 Leidèjo žodis. Lietuvos albumas. Kaunas, 1921, p. 289-290.

20 Biržiška, V. Asmenvardžiai (S, Sch, Sz) su trumpomis biografinèmis žiniomis „Lietuviškajai enciklopedijai“. LNB RS, f. 32-30, 1. 136. 
II tomo įžangoje 1934 metais rašyta, kad „skeptikų, nepasitikinčių mūsų tautos pribrendimu šiam dideliam žygiui suprasti ir paremti, spejjimai pasirodè buvę nepagrissti (...) leidejai, visuomenè ir bendradarbiai ji gerai suprato ir paremé, tuo igalindami juos nesitenkinti 3-4 tomų leidiniu (...) Tikslingai ją pavadinę „Lietuviškąja enciklopedija" ne tik stengèmès duoti kuo daugiau žinių apie Lietuvą ir lietuvius, bet ir iš viso enciklopedijos medžiagą tvarkyti mūsų reikalų atžvilgiu“ (p. V). Latviai tuo metu jau leido trečios enciklopedijos dešimtą tomą.

Tačiau i LE pakliuvo ne visi akademinio elito atstovai, pavyzdžiui, dr. Byliené, VDU $1930 \mathrm{~m}$. rugpjūčio mènesị deleguota ị Stokholmą kaip oficiali Lietuvos atstové kartu su keturiomis kitomis daktarèmis: VDU klinikos vyresniąja asistente Aldona Birutavičiene, Ema Gilde-Ostachoviene, Sofija Kamberyte ir Agniete Ambraziejūte-Steponaitiene $^{22}$. Iš jų tik A. Ambraziejūtė-Steponaitienès trumpa biograma yra išspausdinta LE.

Stasys Yla LKMA 50-mečio sukakties proga paskaitoje Niujorke pateikè veiklos apžvalgą, kur paminèjo neigyvendintą akademijos užmojị išleisti Lietuvos kultūrininkų enciklopediją „Žymesnybių žodyno“ pavadinimu. Sumanymas rengti ŽŽ kilo prelatui A. Dambrauskui 1924 metais LKMA valdybos posèdyje, o redaktoriai pakaitomis buvo Juozas Tumas, Pranas Penkauskas ir Juozapas Eretas. Medžiaga pradèta rinkti 1927 metais ir iki 1939 metų tam reikalui išleista per 1300 litų. Šiuo darbu buvo susidomejjusi LE ir vede derybas medžiagą perimti. Darbas, mašinèle perrašyti 5 tomai, okupantui užèmus Lietuvą, liko neatspaustas. Tačiau buvo išleistas stambus A. Jakšto veikalas „Užgesę žiburiai“, skirtas žymiųjų lietuvių ir nelietuvių kultūrinin$\mathrm{kų} \mathrm{biografijoms} \mathrm{s}^{23}$.

Knygotyrininkė Audronė Glosienè teigia, kad LE - neeilinis mūsų knygos istorijos faktas jau tuo, kad ji yra pirmasis tokio tipo leidinys lietuvių kalba. Ji priejo išvadą, kad ŽŽ buvo paralelus, o ne alternatyvus leidinys - dubliavo LE ${ }^{24}$. Priežastys, kodèl $\check{Z} Z \check{Z}$ neišèjo, yra kelios - finansiniai keblumai, neaiški koncepcija ir paskirtis, todèl negalèjo nei konkuruoti su LE, nei jos papildyti, be to, LKMA neturejo pakankamai pajėgų ${ }^{25}$. Loretos Pakalniškienès duomenimis, 1934 metais jau buvo surinkta apie 2800 biografijų, visiems darbams išleista 121400 litų, 1935 metais ŽŽ darbai buvo sustabdyti, nes Vyriausybé nebeskyré lèšų, motyvuodama, kad jis iš dalies giminingas leidžiamai LE' ${ }^{26}$. Galima spèti, kad garsiai neišsakomas motyvas buvo ir tas, kad ŽŽ buvo LKMA rengiamas leidinys, o katalikiškosios „srovès“ padètis tautininkų valdymo metu buvo „apgultos tvirtovès“ - žlugo iniciatyva ịkurti katalikišką universitetą, taip pat sunku buvo išsilaikyti VDU Teologijos-filosofijos fakultetui.

Prof. Tumčienè. Antrojo tarptautinio pediatrų kongreso įspūdžiai. Medicina. 1931, 3: 1.

[žiūrèta 201210 25]. <http://www.aidai.us/index.php?option=com_content\&task=view\&id=8 08\&Itemid $=123>$.

4 Glosienè, A. „Lietuviškoji enciklopedija“ ir „Žymesnybių žodynas“: leidimo problemos. Knygotyra. 1993 (1994), 20: 61.

Ibid, p. 70.

Pakalniškienè, L. „Žymesnybių žodyno“ pėdsakais. Tarp knygų. 2009, liepa-rugpjūtis, 7/8: 15-16. 
Adomas Dambrauskas-Jakštas Unei Babickaitei-Graičiūnienèi rašè, kad „Žymesnybių žodynas" seniai būtų „gatavas“, bet „Dabar tame žodyne mums dažnai atsitinka patirti štai kas; sužinoję apie tą ar kitą Lietuvos „žymesnybę“ rašom joms: „būkit gerutès mums pranešti pluoštą žinių apie save mūsų žodynui “' ${ }^{27}$. I tai dažnai negaunam jokio atsakymo. Rašom antru atveju. İ tai gaunam paaiškinimą, kad jų kuklumas neleidžiąs apie save rašyti. Rašom iš naujo, kad mes nemanom kėsintis ant jų kuklumo, nereikalaujam, kad jie save į padanges keltų, kad panegirikas rašytų, bet kad suteiktų vien trumpą informaciją apie savo gyvenimą ir veikimą. Neretai ir tie paaiškinimai nueina niekais, nes reikiamų informacijų nesulaukiam. Tenka pačiai redakcijai tų žinių rinktis. Ji tai ir daro, kai tenka rašyti apie mirusias „žymesnybes“. Gyvosios galètų nemaž mums palengvinti tą darbą, bet nenori. Tačiau to nežiūrèdami jau turim susirinkę apie 4000 trumpų biografijelių “28.

ŽŽ tikrinimo komisijai (Zenonui Ivinskiui, Juozui Girniui ir Antanui Saliui) skirtame redakcijos sekretoriaus Balio Laukaičio pranešime pažymima, kad 1924 metais norèta žodyną pavadinti „Lietuvių biografijomis“, tačiau $1927 \mathrm{~m}$. lapkričio 6 d. LKMA valdybos posėdyje nutarta pavadinti „Lietuvos žymesnybių biografijomis“, veikalą numatyta įtraukti „visus kuo nors pasižymejjusius be skirtumų tautų, konfesijų, politinių pažiūrų “29. Ten pat rašoma, kad „žymesnybès sąvoką galima imti siaurai, t. y. žymesnybėmis laikyti tik pačius didžiuosius rašytojus, menininkus, veikejjus ir t. t. Bet kadangi mūsų tauta nedidelè ir teturi nedaug pasaulinio masto žmonių, tai ir tokių didelių žymesnybių bus, palyginti, nedaug. (...) Tačiau šalia pačių didžiųjų mūsų tautos veikejjų yra ir mažiau žymių žmonių, kurie vis dèlto yra mūsų tautai nusipelnę. O tokių vidutinio masto žymesnybių ir yra daugiausia. - Gyvenimą kuria ne vienas ir ne keli asmenys, bet ištisa organiška darbininkų grupé. 1927 metais ŽZ̆Z̆ redaktoriumi išrinktas kanauninkas Juozas Tumas, 1929 m. sausị - kanauninkas Pranas Penkauskas, $1931 \mathrm{~m}$. sausio $21 \mathrm{~d}$. - Juozas Eretas, kuris sekretoriumi pasikviete Alekș̣ Didžpetrị, dirbusị iki 1933 m. vasaros, spalio 1 d. jị pakeite Balys Laukaitis. Žymesnių Lietuvos kariškių biografijas pateikè pulkininkas Jonas Laurinaitis, duomenų apie žydų veikejjus - Chackelis Lemchenas, iš JAV duomenis siuntė Jurgis Draugelis.

Kaip vykdavo „žymesnybių“ atranka, ịspūdị galima susidaryti ir iš redaktoriu pastabų paraštėse. Prie žydų poetès, vertèjos Saros Aizinaitès (g. 1911 m. Ramygaloje), kuri į žydų kalbą išvertè ir „Idiše Štime“ išspausdino Vinco Krèvès „Sutemų pasakas“, verčia Antano Vienuolio „Paskenduolę“, ŽŽ redaktoriaus A.K. (nepavyko identifikuoti - V.S.) parašyta: „Iš viso studijuojančius un-te žmones vargu ar verta žodynan

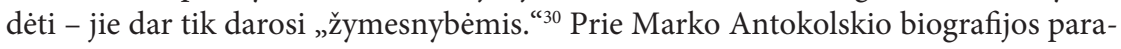
LNB RS, f. 12-156, 1. 4.

Ibid., 1. 4.

29 Pranešimas „Žymesnybių žodyno“ Tikrinimo komisijai. 1934. LNB RS, 1. 29-1620, 1. 1. 
šyta: „galima be jo apsieiti, nes Lietuvai, išskyrus joje gimimą, nieko nenusipelne“ ${ }^{\text {“31 }}$. Anot B. Laukaičio, svarbiausias atrankos į ŽZ̆ kriterijus buvo tautiškumas ${ }^{32}$.

\section{Reputacinio elito tyrimo šaltiniai sovietmečiu}

Rengiant „Lietuviškąją tarybinę enciklopediją“ (LTE), 1979 metų pradžioje vyko Vyriausiosios enciklopedijų redakcijos Mokslinès redakcinès tarybos posėdis, kuriame svarstyti ir „žymiųjų“veikejjų atrankos principai. Robertas Žiugžda akcentavo atrankos ideologinius trūkumus: „....) ar čia nèra sudètas pilnas rašytojų sąjungos narių sąrašas. Daug jų. Literatūros, meno pavardžių daug, o mokslo absoliučiai nèra. Leninas atvyko ị Vilnių - nėra. Tarybų Sąjungos didvyrių - nèra. Melnikaités nėra. Socialistinių darbo didvyrių nèra" ${ }^{\text {"33. }}$. Romas Šarmaitis siūlè praplèsti atrankos kriterijus: „Enciklopedijoje skelbiamos žymių žmonių biografijos labai reikalingos. (...) Biografijų yra mažai paskelbtų. Jų reikètų žymiai daugiau. Reikètų skelbti ne tik akademikų, daktarų biografijas, bet ir perspektyvių mokslininkų-mokslų kandidatų, kurie po kelių metų irgi bus daktarai““34. Jonas Zinkus pareiškè: „Visiškai atsisakę tarybinių mokslų kandidatų, o atskirais atvejais net ir kandidato laipsnio neturinčių tarybinių mokslo ir kultūros veikejjų aprašymo, sumenkintume Tarybų Lietuvos laiméjimus ir tuo pačiu dirbtinai išpūstume buržuazijos valdymo laikotarpio reikšmingumą. Anuometinis daktaras juk yra ne kas kita, kas dabartinis kandidatas (...) Sumažinome numatytų aprašyti reakcinių užsienio lietuvių veikejjų skaičių. Bet svarbiausius iš jų vis dèlto aprašome. Ypač tuos, kurie plačiai žinomi Lietuvoje, dažnai minimi mūsų literatūroje. Kai ką aprašome net iš tokių reakcinių veikejų, kurie nebuvo aprašyti MLTE. Pvz.: I tome aprašytas visiems žinomas lietuvių tautos išdavikas Ambrazevičius. Atrinkdama biografijas, enciklopedijų redakcija vadovaujasi visų tarybinių enciklopedijų nuostatais, pagal kuriuos didžioji dalis enciklopedijoje aprašomų žmonių yra aprašomi už jų nuopelnus visuomeninèje, mokslinèje ir kultūrinèje veikloje. Tačiau tai nereiškia, kad enciklopedija yra savotiškas panteonas ar paminklas pažangiesiems praeities ar "garbès lenta“ pažangiesiems dabarties veikejjams. Būtinais atvejais tarybinè enciklopedija privalo pateikti žinių ir apie reakcinius veikejjus, žinoma, su atitinkamu jų veiklos ịvertinimu. (...) LTE nebus taip smulkiais atskirais straipsneliais aprašinejjamos reakcinių lietuvių emigrantų, hitlerininkų ir Vakarų imperialų talki-

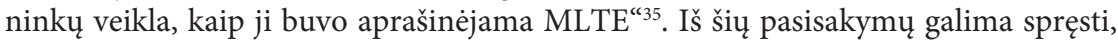
kad ị sovietines enciklopedijas pavykdavo ịtraukti ir politiniam režimui nepalankių

31 Žymesnybių žodynas, supra note 30, p. 244.

32 Glosienè, A. „Lietuviškoji enciklopedija“ ir „Žymesnybių žodynas“, supra note 24, p. 69.

33 Vyriausiosios enciklopedijų redakcijos Mokslinès redakcinès tarybos posèdžio, ịvykusio 1979 m. sausio 5 d. protokolas. LCVA, f. R-593, ap. 1, b. 36, 1.

34 VER mokslinès redakcinès tarybos posèdžio, įvykusio $1976 \mathrm{~m}$. gruodžio $16 \mathrm{~d}$., protokolas. LCVA, f. R-593, ap. 1, 1. 27.

J. Zinkaus pranešimas MRT posèdžiui, 1976 m. kovo 16 d. LCVA. f. R-593, ap. 1, b. 27, 1. 49-53. 
veikejų biografijas, tačiau su atitinkamais „ịvertinimais“. Mažoji lietuviškoji tarybiné enciklopedija (MLTE) buvo pirmoji pokarinè enciklopedija nerusiškose Sovietų sąjungos respublikose. Jai istorinių asmenų vardyną sudarinėjo redaktorius Vincas Martinkenas. Vyriausasis redaktorius buvo LSSR mokslų akademijos prezidentas Juozas Matulis. Istorikas Vytautas Merkys atsiminimuose minejo, kad vyriausiasis istorijos skyriaus redaktorius Juozas Žiugžda negailestingai cenzūruodavo straipsnius, o kai kuriuos „buržuazinius“ veikejus (pavyzdžiui, Lietuvos prezidentą Kazi Grinių) išvis išbraukdavo. Straipsnių autoriai išsireikalavo iš vyriausiojo enciklopedijos redaktoriaus kai kuriuos "pataisymus“ ir išcenzūravimus atitaisyti ${ }^{36}$. Atrankoje ¿ MLTE nuopelnai turejo savo hierarchiją - pirmenybé buvo teikiama TSKP nariams, po to - „buržuazinių laikų pogrindžio komjaunuoliams“, TSRS ir Lietuvos TSR AT deputatams, apdovanotiesiems Lenino premija, Mokslų akademijos nariams, TSRS didvyriams, socialistinio darbo didvyriams, galiausiai - nusipelniusiems mokslo ir technikos veikejjams, nusipelniusiems gydytojams, mokytojams ir kt. ${ }^{37}$

Atrankos ị sovietines enciklopedijas kriterijai priklausè ne tik nuo nuopelnų sistemai, bet ir kokiai veiklos sričiai asmuo priklausè. Vilius Ivanauskas teigia, kad negamybinèje (švietimo, mokslo, kultūros) srityje dirbę vadovaujantieji kadrai ir kultūrininkai buvo labiausiai apribota nomenklatūros grupè. Sugebėję atitikti ideologinius kontrolierių lūkesčius, nacionalinę kultūrą administravę (ar produkavę) kultūrininkai, ypač „pripažinti autoritetai“, susilaukdavo viešo pripažinimo ir didelès valdžios paramos, tačiau idėjiniu požiūriu turejo gana siaurą valdžios lauką. Technokratai gamybinëje srityje dirbę vadovaujantieji kadrai, buvo dinamiškiausia sovietinès nomenklatūros grupe $\dot{e}^{38}$. Ji sovietinèse enciklopedijose iš akademinio ar kultūrinio elito atstovų buvo reprezentuojama gausiausiai.

\section{Reputacinio elito tyrimo šaltiniai Lietuvos Respublikoje nuo 1990 metur}

Po 1990 metų nepriklausomos valstybès atkūrimo, Lietuvoje atsirado nauja enciklopedinių leidinių rūšis, kurios iki tol nebuvo, bet kuri Vakarų pasaulyje turejo jau šimtmetinę tradiciją. Tai „Kas yra kas“ (Who is Who) biografinis žinynas. Pirmojo lietuviško leidinio parengejjas Vaclovas Paulauskas pratarmèje rašè, kad leidinio tikslas - supažindinti skaitytojus su asmenimis, užimančiais vadovaujančius postus Lietuvoje, tad kiekviename straipsnelyje pirmiausia ir pasakoma, kokias pareigas eina aprašomasis asmuo - Aukščiausios Tarybos deputatai, Lietuvos Respublikos ministrai, departamentų generaliniai direktoriai, didžiausių politinių partijų ir visuome-

36 Merkys, V. Atminties prošvaistès. Vilnius: Versus aureus, 2009, p. 190.

37 Metodiniai nurodymai „Mažosios lietuviškosios tarybinès enciklopedijos" rengéjams. Vilnius, 1963, p. 41, 43.

38 Ivanauskas, V. Lietuviškoji nomenklatūra biurokratinèje sistemoje: tarp stagnacijos ir dinamikos 1970-1988 m. Daktaro disertacijos santrauka. Klaipèda-Vilnius, 2008, p. 52. 
ninių judejimų lyderiai, stambiausių Lietuvoje veikiančių religinių bendruomenių dvasiniai vadovai. Iš viso beveik 200 personalijų. Tam tikra problema yra buvęs ar esamas priklausymas komunistų partijai ${ }^{39}$. Taigi, atranka buvo gana ribota - beveik vien tik tuometinis politinis elitas.

Nuo 1995 metų bendrovei „Neolitas“ pradejus leisti „Kas yra kas“ leidinius, pirmosios iš šių knygų įvade rengèjai rašè, kad tokių leidinių Lietuvai labai trūko, nes, skirtingai negu kituose enciklopediniuose leidiniuose, akcentuojamas dabarties momentas ${ }^{40}$. „Kas yra kas“ leidiniai Vakarų pasaulio šalyse jau turejo beveik šimto metų tradiciją. Jų tikslas - informuoti visuomenę apie iškiliausius, žymiausius ir daugiausiai pasiekusius valstybès žmones. Leidejai, siekdami padaryti kuo mažiau klaidų atrankoje, stengèsi kiek įmanoma konsultuotis su kultūros, mokslo, verslo sričių, imonių specialistais. Pasakytina, kad reputacinio elito atranka tapo labiau komercializuota. 2011 metais bankrutavus „Neolitui“ šio leidinio leidyba buvo nutrūkusi, nuo 2014 metų ją atnaujino uždaroji akcinè bendrovè „Leidybos studija“.

\section{Išvados}

Enciklopediniai leidiniai paprastai apima ir žymiausius žmones, kuriems statomi paminklai, jų vardais pavadinamos gatvès, jie apdovanojami ordinais ir premijomis, todèl galima enciklopedijas ir biografinius žinynus laikyti patogiausiais ir išsamiausiais reputacinio elito tyrimo šatliniais. Pirmasis lietuviškosios nacionalinès enciklopedijos leidybos idèją pasiūlè Mečislovas Davainis-Silvestraitis jau 1907 metais. Pagrindiniai Lietuvos Respublikos reputacinio elito tyrimo 1918-1940 metais šaltiniai 1933-1944 metais leistoji nacionalinè „Lietuviškoji enciklopedija“ bei rankraštyje likęs LKMA inicijuotas „Lietuvos žymesnybių žodynas“. It „Žymesnybių žodyną“ numatyta įtraukti visus kuo nors pasižymèjusius be tautų, konfesijų, politinių pažiūrų skirtumų, tačiau atrenkant žymius žmones daugiausia buvo įtraukiami katalikai visuomenininkai, mokslininkai ir dvasininkai, taikomas „tautinis“ atrankos kriterijus. İ vèlesnio laikotarpio enciklopedijas išeivijoje įtraukiama asmenų, kurie dar nebuvo pripažinti savo amžininkų, o jų darbų reikšmè îvertinta praẻjus dešimtmečiams.

Atrankos ị sovietines enciklopedijas kriterijai priklausė ne tik nuo nuopelnų sistemai, bet ir kokiai veiklos sričiai asmuo priklausè. „Technokratams“ ir komunistų partijos veikejjams buvo rodomas didesnis demesys negu „kultūrininkams“, be to, enciklopediju pobūdis ribojo to laikotarpio reputacinio elito biografijų skaičių, nes reikejo įtraukti ir apibūdinti ir žymiausius „buržuazinius“ veikejjus.

Atkūrus nepriklausomybę 1990 metais pasirodè pirmieji biografinio žinyno „Kas yra kas“ leidiniai, skirti dabarties reputaciniam elitui reprezentuoti. Jo atranka igavo daugiau komercinị pobūdị.

39 Kas yra kas Lietuvoje. Dabartiniu politikos ir visuomenès veikejų biografinis žinynas. Vilnius: Politika, 1990.

40 Ivadas. Kas yra kas Lietuvoje 95/96. Kaunas: Neolitas, 1995, p. 5-6. 


\title{
Literatūra
}

Bourdieu, P. L'illusion biographique. Actes de la recherche en sciences sociales. 1986, Nr. 62/3.

Braudy, L. The Frenzy of Renown. Fame and its History. New York, Ofxord, 1986.

Čepaitienè, R. Nacionalinis miestas (III) [interaktyvus]. [žiūrèta 2014-02-10]. <http://www.bernardinai.lt/straipsnis/2013-01-23-rasa-cepaitiene-nacionalinis-miestas/94144/print>.

Glosienè, A. „Lietuviškoji enciklopedija“ ir „Žymesnybių žodynas“: leidimo problemos. Knygotyra. 1993 (1994), 20.

Ivanauskas, V. Lietuviškoji nomenklatūra biurokratineje sistemoje: tarp stagnacijos ir dinamikos 1970-1988 m. Daktaro disertacijos santrauka. Klaipeda-Vilnius, 2008.

Karady, V. Educated Elites in PreSocialist Hungary - 1867-1948. Issues, Approaches, Sources and Some Preliminary Results of an Overall Survey. Historical Social Research. 2008, Vol. 33, Issue 2.

Masiulis, K.; Sudnickas T. Elitas ir lyderyste. Vadovèlis. Vilnius: Mykolo Rome- rio universiteto Leidybos centras, 2008, p. 20.

Matonyte, I. Posovietinio elito labirintai. Vilnius: Knygiai, 2001.

Merkys, V. Atminties prošvaistès. Vilnius: Versus aureus, 2009.

Metodiniai nurodymai „Mažosios lietuviškosios tarybinès enciklopedijos" rengéjams. Vilnius, 1963.

Pakalniškienè, L. „Žymesnybių žodyno“ pèdsakais. Tarp knygų. 2009, liepa-rugpjūtis, $7 / 8$.

Research Methods for Elite Studies, edited by George Moyses and Margaret Wagstaffe. Department of Government, University of Manchester, London, Allen, Boston-Sydney-Wellington. Urbonavičienè, E. Projektas „Iškiliausi tarpukario kauniečiai“. Kauno istorijos metraštis. T. 12. Kaunas: VDU leidykla, 2012.

Varga, M. Dictionaries of National Biography. Atlas of European Historiography. The Making of a Profession 1800-2005, ed. I. Porciani, L. Raphael, Palgrave Macmillan, 2010.

\section{THE SOURCES OF LITHUANIAN REPUTATIONAL ELITE STUDIES}

\author{
Valdas Selenis \\ Lithuanian Culture Research Institute, Lithuania
}

Summary. Reputational elite in this article is considered to be not only the most famous, authoritative, "the most meritorious men of the state and nation", the most influential "famous people" (Men of Fame) in the society, awarded in prizes, medals and other evaluational attributes, but every person who has entered the encyclopaedias and "who is who" type of publications. In Western Europe, from the beginning of the twentieth century biographical reference books became a "canonization" form of the 
most prominent national and state actors in emerging "small" nations, as well as a sign of modern nationalism in the era.

The main source of research of Lithuanian state reputational elite in the 1930s is Lietuviškoji enciklopedija, which is the best and only Lithuanian encyclopaedia from inter-war period. The idea for it was first introduced in 1907, but it was realized only in 1931. This encyclopaedia contains fragmentary and some vast and informative biographical articles. Unfortunately, because of the Soviet and Nazi occupations, this encyclopaedia was not finished (10th volume had only reached letter L). Both sources from this period, Lithuanian Encyclopaedia and unpublished Dictionary of Celebrities, intended to include "all distinguished people, without any distinction of nationality, religion, political views", but in fact, Lithuanian ethnical and Catholic confessional criterions of selection dominated.

Selection of "prominent people" in Soviet encyclopaedias depended not only on ideological background, but also on profession. Technocrats had much more advantageous positions than "cultural workers".

After re-establishment of the independence of the Lithuanian Republic in 1990, the very first "who is who" biographical dictionaries were released. These publications are a source of modern Lithuanian reputational elite research, which possibly would begin in future.

Keywords: reputational elite, encyclopaedias, biographical dictionaries.

Valdas Selenis, Lietuvos kultūros tyrimų instituto vyresnysis mokslinis darbuotojas. Mokslinių tyrimų kryptys: XIX-XX a. Lietuvos kultūros istorija, biografistika.

Valdas Selenis, Lithuanian Culture Research Institute, senior scholar. Research interests: Lithuanian cultural history in 19th-20th centuries, biographies. 